\title{
Online Escape Room during COVID-19: A Qualitative Study of Social Education Degree Students' Experiences
}

\author{
Ana Manzano-León (D), José Manuel Aguilar-Parra*D, José M. Rodríguez-Ferrer*(D), Rubén Trigueros, \\ Rocío Collado-Soler, Cristina Méndez-Aguado, María Jesús García-Hernández and Laura Molina-Alonso
}

Citation: Manzano-León, A.; Aguilar-Parra, J.M.; Rodríguez-Ferrer J.M.; Trigueros, R.; Collado-Soler, R.; Méndez-Aguado, C.; GarcíaHernández, M.J.; Molina-Alonso, L. Online Escape Room during COVID-19: A Qualitative Study of Social Education Degree Students' Experiences. Educ. Sci. 2021, 11, 426. https://doi.org/10.3390/

educsci11080426

Academic Editor: Huei Tse Hou

Received: 22 July 2021

Accepted: 10 August 2021

Published: 12 August 2021

Publisher's Note: MDPI stays neutral with regard to jurisdictional claims in published maps and institutional affiliations.

Copyright: (c) 2021 by the authors. Licensee MDPI, Basel, Switzerland. This article is an open access article distributed under the terms and conditions of the Creative Commons Attribution (CC BY) license (https:/ / creativecommons.org/licenses/by/ $4.0 /)$.
Department of Psychology, University of Almería, 04120 Almería, Spain; aml570@ual.es (A.M.-L.); rtr088@ual.es (R.T.); rcollado98@gmail.com (R.C.-S.); cristinamendezaguado@gmail.com (C.M.-A.); marigahe@hotmail.com (M.J.G.-H.); laura97eduso@gmail.com (L.M.-A.)

* Correspondence: jmaguilar@ual.es (J.M.A.-P.); joserf@cop.es (J.M.R.-F.)

Abstract: Confinement due to the COVID-19 pandemic has hastened an educational shift from face-to-face to online classrooms. This distanced education seeks to achieve learning goals mediated by technology as they would be achieved in the face-to-face classroom, without ignoring the psychological and social impact that COVID-19 has had on students and teachers. Faced with this situation, the use of online educational escape rooms has been proposed as a motivating strategy for students to review curriculum content in a cooperative and fun way. A qualitative investigation was carried out to explore the perceptions of university students in the Social Education degree program after the implementation of an educational escape room. Our main findings are that most students found that it allowed them to interact with their peers beyond traditional education, that it was useful for their learning and that it was a pleasant activity. However, it was also mentioned that it can be a stressful activity as being an online activity, some students may have connectivity problems. It is concluded that online escape rooms can be active and effective learning strategies for university students.

Keywords: escape room; educative innovation; cooperative learning; higher education

\section{Introduction}

During the period of health emergency and confinement caused by the COVID-19 pandemic, the educational system from early childhood education to university education has had to adapt its face-to-face methodology to an online methodology in a hasty and forced manner [1]. The transition to that virtual model was the only opportunity to continue teaching. However, it was limited by different factors, including the digital divide across students, the lack of digital resources and the scarce training of teachers in digital skills [2].

In addition, the witnessing of a global pandemic and the confinement have been a challenge for the mental health of both teachers and students due to increased feelings of uncertainty, stress, and anxiety [3]. These feelings can create unfavorable effects on learning and psychological health [4].

To try to alleviate these negative effects on the mental health of students and promote motivating teaching, it is necessary to implement active learning strategies that can be recreated in online teaching. This research explored the perceptions of university students regarding the use of a playful learning strategy, educational escape rooms, during confinement in Spain in the second quarter of the 2020-2021 academic year. Escape rooms are immersive narrative games in which participants are required to solve puzzles to escape from a room. Escape rooms are currently a popular leisure activity for young people. A global survey found that $19 \%$ of escape room players are young, under 21 years old [5], so it could be an interesting activity to adapt it and use it in college education. Escape rooms are an innovative and playful educational strategy that is increasingly incorporated into education and research. Their main benefit is that they can facilitate motivation toward learning through playful challenges. 
Escape rooms have a direct relationship with gamification due to their playful nature that favors positive behavior [6]. Different systematic and meta-analysis reviews indicate that this playful strategy has an overall positive effect on student learning, participation, and academic performance, as well as an improvement in school motivation [7-9].

Mainly in university education, research has been carried out in health sciences, particularly in nursing, showing that escape rooms can be very effective in consolidating routines, concepts, and basic procedures for professional development and at the same time, teach important skills to deal with stressful situations under time pressures [10-12]. They are also used in other areas of knowledge such as social sciences. For example, after conducting an escape room, master's students showed a statistically significant improvement in their academic performance, educational flow, and classroom climate, as well as qualitatively confirming that escape rooms can be fun and motivating for students [13]. However, escape rooms, like other playful strategies such as game-based learning or gamification, have possible disadvantages to consider, such as potentially consuming too much time, excessive competitiveness between students, too much noise can be generated or the playful content can exceed educational objectives [14].

Recent studies on their educational use during the pandemic confinement offer promising results with some limitations. For example, the study carried out by Da Silva [15] showed that the use of an interactive game-based application created a pleasant learning environment, although both the control group (that conducted their class in a traditional way) and the experimental group obtained similar results in learning outcomes. On the other hand, the use of gamified digital platforms such as Classcraft were also effective in improving student engagement during confinement, however, in the long term, students may have difficulties participating with asynchronous tools [16].

Other studies indicate that educational escape rooms under normal conditions have benefits in the motivation, engagement, and learning outcomes of the students [17-19]. For this reason, we proposed a qualitative research study that explores the reflections of university students in educational sciences on the use of escape rooms to review curricular content during the confinement of COVID-19. Our research hypotheses are: (1) the students will consider the escape room fun and motivating; (2) the escape room will have a positive impact on their learning; and (3) the escape room is going to be an effective strategy for online teaching.

\section{Materials and Methods}

\subsection{Participants}

This study implemented an educationally innovative program through escape rooms in the subject of "Socio-educational Programs in Children, Youth, Adults and Seniors" in the degree of Social Education at the University of Almería during the 2019/2020 academic year. This subject is part of the annual training itinerary for the degree in Social Education, which is divided into 5 subjects per semester. The main objective of this subject is to explore and design socio-educational programs for different groups in situations of social vulnerability.

This subject is divided into a theoretical part where the teacher traditionally exposes the curricular contents and a practical part where the students delve into the design of social programs. The objective of using an escape room is to sensitize students to gender violence in a relationship and learn about programs to prevent or alleviate gender violence, since gender violence is a topic of the subject.

This escape room was designed so that the students of this subject could participate voluntarily. The teams that participated in the escape room got 0.25 extra points in the practices of the subject.

To select the participants, a convenience sample was chosen. The inclusion criterion for the experimental group was a willingness to participate in the escape room organized by the teaching staff. A total of 56 students (41 women and 15 men, aged between 19 and 
44 years) participated in the escape room and voluntarily answered the online survey of open questions.

All participants received information about the project and gave written informed consent in accordance with the Declaration of Helsinki. Prior to data collection, the students were informed about the nature of the study and were assured of their anonymity. Ethics approval was obtained from the Research Ethics Committee of the University of Almería (Ref. UALBIO 2021/01).

\subsection{Design and Implementation of the Educational Escape Room}

In the second semester (a four-month period) of the 2019/2020 academic year, home confinement occurred in Spain, therefore all theoretical and practical teaching was carried out online. For this reason, the escape room was designed online, with the Wix and Genially platforms, and was implemented cooperatively through the Blackboard teaching platform.

The escape room (see Figure 1) consisted of 4 rooms in a family home where each team of students determined what happened since María (a fictional character) disappeared. After several puzzles and challenges, the narrative is resolved when the students learn that María has managed to report her abusive husband and is in a safe shelter together with her young son. The escape room is available at the following link: https:/ / diversatics.wixsite. com/escapeduso (accessed on 11 August 2021).

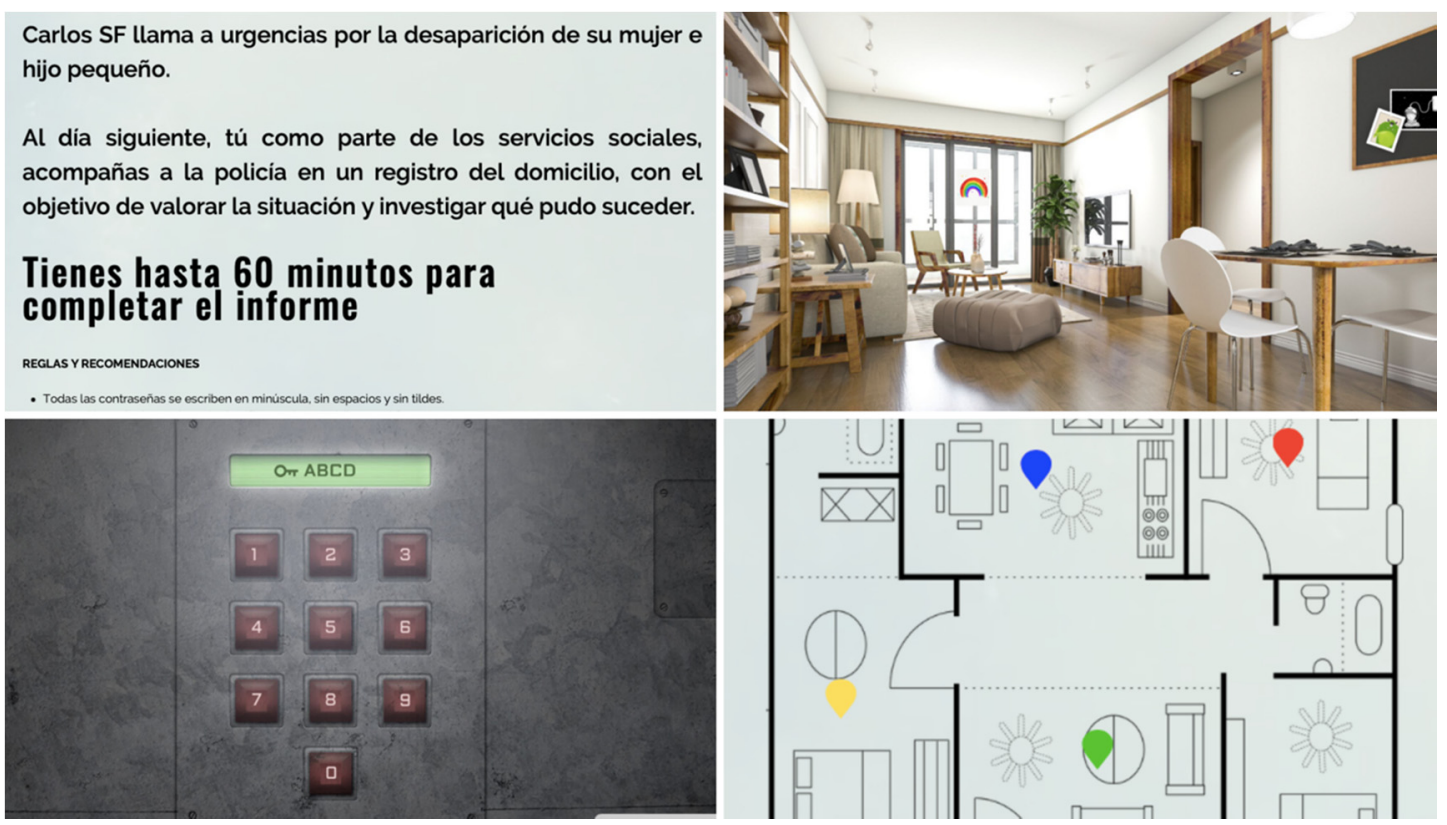

Figure 1. Escape room design.

In the class schedule, it was explained to the students that they were going to complete an escape room and what is involved. The students were randomly divided into teams of 4 to 6 players in the online work rooms and the escape room link was provided. The teacher acted as a game master for any doubts that students had throughout the escape room.

\subsection{Instruments}

After conducting the escape room, the students were asked to voluntarily answer a qualitative online questionnaire with open questions [20]. An ad hoc questionnaire with six open questions was designed, with the Google Forms platform, to find out the opinions of the students about their experience in the escape room. This format was used to respect anonymity so that students could freely express their opinions regarding the escape room. The general rules of the escape room were: 
- Carry out the escape room as a team through the university's Blackboard platform.

- Contact the teacher if they had any questions or could not continue the game (if they did not know how to solve a challenge).

- $\quad$ Do not speak through the student chat to avoid spoiling other classmates' tasks.

- Put all passwords in lowercase and without accents.

- Work as a team and debate among colleagues.

Table 1 summarizes the challenges for each room, mechanics, and related learning objectives.

Table 1. Design of the escape room.

\begin{tabular}{|c|c|c|}
\hline Rooms & Mechanics/Challenges & Learning Objectives \\
\hline Starting screen & $\begin{array}{l}\text { (1) Read the information provided (narrative) and press start to } \\
\text { begin }\end{array}$ & Meaningful reading \\
\hline I iving room & $\begin{array}{l}\text { (1) Find clues to open the lock in the living room (Playful } \\
\text { challenge of opening boxes) }\end{array}$ & Ability to make judgments \\
\hline Living room & $\begin{array}{l}\text { (2) Interpret a coded message written in Caesar code about } \\
\text { María's situation }\end{array}$ & Ability to communicate (social aptitude) \\
\hline & $\begin{array}{l}\text { (1) Open a padlock with the tracks from the living room and } \\
\text { kitchen }\end{array}$ & \\
\hline Kitchen & $\begin{array}{l}\text { (2) Read an intervention program for victims of gender violence } \\
\text { and recognize a code from random letters in bold to open a lock } \\
\text { in the child's bedroom. }\end{array}$ & $\begin{array}{l}\text { Knowledge of psychosocio-educational } \\
\text { programs }\end{array}$ \\
\hline Child's bedroom & $\begin{array}{l}\text { (1) Recognize the Caesar code for the hidden message in the } \\
\text { room } \\
\text { (2) Open the box with the kitchen program code } \\
\text { (3) Inside the box, crack the code to enter the master bedroom }\end{array}$ & $\begin{array}{l}\text { Ability to make judgments } \\
\text { Ability to communicate (social aptitude) }\end{array}$ \\
\hline Main bedroom & $\begin{array}{l}\text { (1) Solve the drawer lock (Quizziz) } \\
\text { (2) Decrypt the computer password } \\
\text { (3) Interpret the final story (What happened to María and what } \\
\text { resources did she need to get out of the situation of violence?) }\end{array}$ & $\begin{array}{l}\text { Diagnose and analyze the factors and } \\
\text { processes that intervene in the sociocultural } \\
\text { reality in order to facilitate the explanation } \\
\text { of the socio-educational complexity and the } \\
\text { promotion of social intervention. }\end{array}$ \\
\hline
\end{tabular}

With these playful challenges, it was intended that students reinforce this part of the subject's content (gender violence) through an attractive experience. Previous research shows how escape rooms, thanks to their challenging design and cooperative learning capacity, facilitate student learning [21,22].

\subsection{Data Analysis}

An online open question survey was proposed for the students to voluntarily answer once they had completed the escape room. The data analysis was carried out through content analysis based on grounded theory [23]. As the survey was online, the transcription was automatic and was introduced in the ATLAS.ti software for Mac (version 9, ATLAS.ti Scientific Software Development GmbH, Berlin, Germany). An in-depth analysis of categories with labels was carried out. Related codes were grouped into subtopics, and overlapping subtopics were grouped together (See Figure 2). 

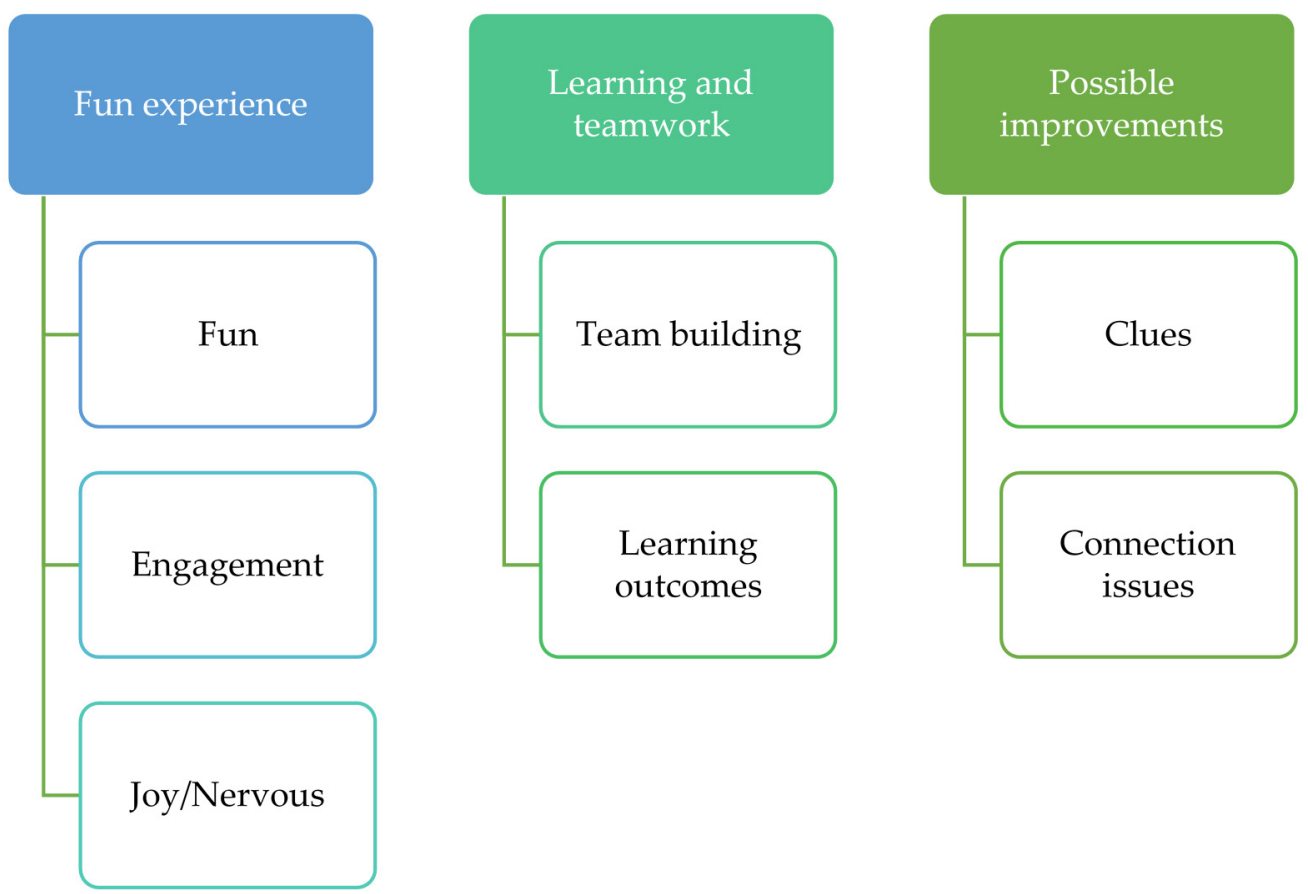

Figure 2. Qualitative results of the escape room.

\section{Results}

After the analysis of the interviews were conducted with the students, the following categories were identified (see Figure 2 and Table 2).

Table 2. Qualitative results after implementing the escape room.

\begin{tabular}{|c|c|c|}
\hline Main Category & Sub-Category & Illustrative Quotes \\
\hline \multirow{4}{*}{ Fun experience } & Fun & $\begin{array}{l}\text { I have loved playing "Sherlock Holmes". } \\
\text { I love escape rooms! They are super entertaining and help keep your mind active. } \\
\text { Super cool, we would have to do more in all subjects. } \\
\text { The truth is that it has been a great job by the teachers. It has been incredible and fun. }\end{array}$ \\
\hline & Engagement & $\begin{array}{l}\text { A super interesting and innovative dynamic where you learn while having fun. } \\
\text { It has seemed like a very cool experience, to be able to work with classmates online, } \\
\text { the theme that it has had and the way in which it has been developed, the truth is that } \\
\text { I would love to repeat. } \\
\text { What I liked the most was discovering little by little that this woman was a victim of } \\
\text { gender violence, it has been a very immersive experience. }\end{array}$ \\
\hline & Joy & $\begin{array}{l}\text { It seemed like a great idea to get out of the monotony that we are currently } \\
\text { experiencing. } \\
\text { I find it great to get out of the work dynamics—study and do playful activities, } \\
\text { particulary now that we are all at home. }\end{array}$ \\
\hline & Nervous & $\begin{array}{l}\text { I have not been very enthusiastic about the activity, I did not understand what to do } \\
\text { and I do not like to feel that way. }\end{array}$ \\
\hline
\end{tabular}


Table 2. Cont.

\begin{tabular}{|c|c|c|}
\hline Main Category & Sub-Category & Illustrative Quotes \\
\hline \multirow{2}{*}{$\begin{array}{l}\text { Learning and } \\
\text { teamwork }\end{array}$} & Team building & $\begin{array}{l}\text { We have found that we can achieve many challenges through the cooperation of the } \\
\text { group. It has also helped us to reflect on the need for different points of view. } \\
\text { I liked being able to do it with colleagues with whom I have never done any work, } \\
\text { because that way I also interact with them. }\end{array}$ \\
\hline & Learning outcomes & $\begin{array}{l}\text { I have found it very useful, I would like to do more to establish knowledge. } \\
\text { Very interesting and entertaining to learn in a different way from the traditional. } \\
\text { I have found it quite entertaining and dynamic as well as acquiring playful learning. } \\
\text { I have found it fun and innovative, I did not know that an activity like this could be } \\
\text { done related to the subject agenda. }\end{array}$ \\
\hline \multirow{2}{*}{$\begin{array}{l}\text { Possible } \\
\text { improvements }\end{array}$} & Connection issues & $\begin{array}{l}\text { I really liked it, but it frustrated me because sometimes the connection was slow. } \\
\text { It was very interesting, but with the broken microphone I couldn't communicate well } \\
\text { with my teammates. }\end{array}$ \\
\hline & Clues & $\begin{array}{l}\text { I think the escape room online is a bit confusing. } \\
\text { It would be nice if there were more clues inside the escape room, so as not to have to } \\
\text { ask the teacher. }\end{array}$ \\
\hline
\end{tabular}

\subsection{Fun Experience}

Escape rooms have been established as a recreational leisure mode and their use in education is beginning to be investigated due to students' interest. Based on the opinions of the students, it can be affirmed that the majority of students perceive the use of educational escape rooms as a playful and immersive experience, coinciding with previous research $[13,19,24]$.

The students considered the different challenges to be balanced with their abilities and to be a pleasant challenge for them, thus they had fun and were motivated to get out of the escape room. This translated into a greater educational flow [25] and in turn, to greater participation and engagement [26], as mentioned by the students. For example, a student stated that "(The escape room) has been very dynamic. It makes you focused on getting out on time and solving the case, you want to know what happened to the woman and you understand the background of the character and feel relieved when you find out that she is fine". The fact that the escape room had a narrative related to the profession of the students encouraged a greater connection and participation.

Positive emotions have a direct relationship with fun and engagement [27]. The students primarily mentioned the enjoyment of completing the escape room. Previous research has found that playful strategies connect with students and can make them enjoy the teaching [28]. When a situation is pleasant and excites students, it encourages their commitment. On the contrary, some students mentioned that they felt nervous or confused during the escape room, which is an aspect for improvement when designing these strategies in the classroom. To reduce these feelings, an initial tutorial could be added on how escape rooms and clues work in each of the rooms, just like other escape room-themed board games.

\subsection{Learning and Teamwork}

This research aimed to explore the use of escape rooms as an educational strategy to strengthen curricular knowledge in university education. The students considered that in addition to the fun that an escape room can produce, it can also be an effective tool to raise awareness about a certain topic, in this case gender violence, and strengthen the theoretical knowledge taught in the subject.

Additionally, working in teams was well-received by the students. The cooperation and relationships between classmates were highly valued. They affirmed that they felt cohesive and enjoyed working in a group, for example: "It has been easy to coordinate as a team, it has been a long time since we met to do things together in class and I liked going 
back to that" and "I liked learning to play escape room, and more with my classmates, like this it was very enjoyable to learn and review what we saw in class".

\subsection{Possible Improvements}

During the interview, students were asked to mention what they did not like about the escape room or what could be improved. It should be noted that some of the students said that there was nothing to improve. However, any educational activity has a range of improvement. When designing educational escape rooms, it must be taken into account that it is likely that some students have not completed an escape room before or have not played a game for years, making it necessary for the explanation, prior to beginning the escape room, of what they have to do and what they can expect from a team escape room. Still, the perceptions of some students showed that they felt stress or fear of failing from not knowing how to continue without continuous cues.

Technical difficulties are also mentioned regarding hardware (problems with headphones to talk to other colleagues) and software (slow internet connection and problems loading web pages). This has been a big problem for tele-teaching, especially during the confinement period. The university educational system particularly has had problems adjusting from face-to-face teaching to $100 \%$ online teaching and some students did not have the necessary resources for its adequate implementation. The lack of resources and the digital divide have been great challenges during the confinement by the COVID-19 pandemic [29]. One of the reasons for conducting the escape room cooperatively was so that the students could help each other if there was a problem, being able to share their screen and carry out the missions as a team. However, it would be highly recommended to be able to offer technical solutions to the students on top of this to facilitate online teaching.

\section{Discussion and Conclusions}

The main purpose of the application of an online escape room in a university degree course was to offer an innovative learning experience different from the traditional classroom during the COVID-19 pandemic. Designing active learning experiences for students during forced online classes was and continues to be a challenge for university faculties.

The objective of this research was to analyze the perception of the students of the Social Education degree program on the use of educational escape rooms during the 2019-2020 academic year. For this, an escape room was designed related to its content on gender violence in the subject of "Socio-educational Programs in Childhood, Youth, Adults and Seniors", based on a case of gender violence during confinement due to COVID-19 restrictions.

Firstly, it sought to provide new learning experiences that are motivating for students, with the aim of producing positive feelings about the subject to increase their participation, beyond connecting to the online class. This escape room was also made to simulate a real case that they could have as social education professionals, so they have interactive resources that could be useful for their professional future. Previous studies mention the importance of teaching practical content to university students and the benefits of simulations [30], as well as the playful and motivating nature of educational escape rooms [31]. Our results confirmed that escape rooms in university education can awaken the curiosity, participation, and motivation of students. Coinciding with our results, the motivation achieved in the escape rooms has been one of the main advantages found in most of the research on this strategy [32-34].

In addition, the cooperative character of the game allows students to work on other essential competencies in their professional future, communication, and teamwork. The students widely emphasized that they enjoyed working as a team with other classmates. Facilitating activities where students must cooperate favors their social skills such as communication, empathy, respect, and negotiation [35]. Our results coincide with previous studies that indicate escape rooms can be valid tools to promote teamwork, favoring 
interaction between students in small groups, and working on the curricular content in a playful and cooperative way [36].

In general, the students perceived this activity as pleasant and educational, except for a small percentage who suggested that they felt nervous during the activity. In future applications of the escape room, we will try to offer a better initial orientation and offer more feedback during the activity so that participants do not feel incapable of solving the puzzles. This limitation of the tool has been found in other investigations, for example, after the application of an escape room in the degree program of Social Education, the majority of students gave a positive assessment to the activity, however a minority of participants reported having suffered stress and frustration [37].

This study has limitations. First, as it was not an interview, it was not possible to delve into the students' responses that could offer a greater perspective and reflection on the use of escape rooms in the classroom. Second, being a qualitative study and having a relatively small sample, the results are not generalizable.

Future research could study the quantitative impact of escape rooms on academic performance, motivation, and the acquisition of social skills through longitudinal experimental studies with a control group. In addition, its use in combination with other active learning strategies, such as cooperative learning and project-based learning, could be investigated.

This research was concluded by evaluating the use of educational escape roomsspecifically our escape room for the degree program of Social Education-to strengthen the knowledge of university education students and to value them as a motivating strategy, which favors cooperative learning and encourages participation and engagement, even in such adverse circumstances as confinement due to COVID-19.

Author Contributions: Conceptualization, A.M.-L. and J.M.R.-F.; methodology, J.M.A.-P.; formal analysis, L.M.-A. and M.J.G.-H.; investigation, M.J.G.-H.; data curation, J.M.A.-P.; writing-original draft preparation, A.M.-L., R.C.-S. and C.M.-A.; writing-review and editing, A.M.-L.; visualization, R.C.-S. and C.M.-A.; supervision, R.T. All authors have read and agreed to the published version of the manuscript.

Funding: This research has been funded, in part, by the Ministry of Universities through the University Teacher Training Program (FPU2019). The support of the Ministry does not imply acceptance of its contents, which is the sole responsibility of the authors.

Institutional Review Board Statement: The study was conducted according to the guidelines of the Declaration of Helsinki and approved by the Institutional Ethics Committee of University of Almería (UALBIO 2021/01).

Informed Consent Statement: Informed consent was obtained from all subjects involved in the study.

Data Availability Statement: The data that support the findings of this study are available from the corresponding author upon reasonable request.

Conflicts of Interest: The authors declare no conflict of interest.

\section{References}

1. Martín-Cuadrado, A.M.; Lavandera-Ponce, S.; Mora-Jaureguialde, B.; Sánchez-Romero, C.; Pérez-Sánchez, L. Working Methodology with Public Universities in Peru during the Pandemic. Continuity of Virtual/Online Teaching and Learning. Educ. Sci. 2021, 11, 351. [CrossRef]

2. Sahu, P. Closure of Universities Due to Coronavirus Disease 2019 (COVID-19): Impact on Education and Mental Health of Students and Academic Staff. Coreus 2020, 12, 4. [CrossRef]

3. Ozamiz-Etxebarria, N.; Dosil-Santamaria, M.; Picaza-Gorrochategui, M.; Idoiaga-Mondragon, N. Niveles de estrés, ansiedad y depresión en la primera fase del brote del COVID-19 en una muestra recogida en el norte de España. Cad. Saúde Pública 2020, 36, e00054020. [CrossRef]

4. Cao, W.; Fang, Z.; Hou, G.; Han, M.; Xu, X.; Dong, J.; Zheng, J. The psychological impact of the COVID-19 epidemic on college students in China. Psychiatry Res. 2020, 287, 112934. [CrossRef] [PubMed]

5. Nicholson, S. The State of Escape: Escape Room Design and Facilities. Available online: http://scottnicholson.com/pubs/ stateofescape.pdf (accessed on 11 August 2021). 
6. Kapp, K. The Gamification of Learning and Instruction: Game-Based Methods and Strategies for Training and Education; Pfeiffer: San Francisco, CA, USA, 2012.

7. Lister, M. Gamification: The effect on student motivation and performance at the post-secondary level. Issues Trends Educ. Technol. 2015, 3. [CrossRef]

8. Manzano-León, A.; Camacho-Lazarraga, P.; Guerrero, M.A.; Guerrero-Puerta, L.; Aguilar-Parra, J.M.; Trigueros, R.; Alias, A. Between Level up and Game over: A Systematic Literature Review of Gamification in Education. Sustainability 2021, $13,2247$. [CrossRef]

9. Clark, D.B.; Tanner-Smith, E.E.; Killingsworth, S.S. Digital Games, Design, and Learning: A Systematic Review and Meta-Analysis. Rev. Educ. Res. 2016, 86, 79-122. [CrossRef] [PubMed]

10. Brown, N.; Darby, W.; Coronel, H. An Escape Room as a Simulation Teaching Strategy. Clin. Simul. Nurs. 2019, 30, 1-6. [CrossRef]

11. McLaughlin, J.; Reed, J.; Shiveley, J.; Lee, S. Escape Room Blueprint: Central Orientation Contagion Crisis. Simul. Gaming 2020, 52, 104687812095449. [CrossRef]

12. San Martin, L.; Walsh, H.; Santerre, M.; Fortkiewicz, J.; Nicholson, L. Creation of a "Patient" Hospital Escape Room Experience to Reduce Harm and Improve Quality of Care. J. Nurs. Care Qual. 2021, 36, 38-42. [CrossRef]

13. Manzano-León, A.; Rodríguez-Ferrer, J.M.; Aguilar-Parra, J.M.; Martínez Martínez, A.M.; Luque de la Rosa, A.; Salguero García, D.; Fernández Campoy, J.M. Escape Rooms as a Learning Strategy for Special Education Master's Degree Students. Int. J. Environ. Res. Public Health 2021, 18, 7304. [CrossRef]

14. Pisabarro Marrón, A.M.; Vivaracho, C.E. Gamificación en el aula: Gincana de programación. ReVisión 2018, 11, 8.

15. da Silva Júnior, J.N.; de Sousa Oliveira, J.M.; Winum, J.-Y.; Melo Leite Junior, A.J.; Alexandre, F.S.O.; do Nascimento, D.M.; Silva de Sousa, U.; Pimenta, A.T.Á.; Monteiro, A.J. Interactions 500: Design, Implementation, and Evaluation of a Hybrid Board Game for Aiding Students in the Review of Intermolecular Forces During the COVID-19 Pandemic. J. Chem. Educ. 2020, 97, 4049-4054. [CrossRef]

16. Lelli, V.; Andrade, R.M.C.; Freitas, L.M.; Silva, R.A.; Gutenberg, F.; Faria, R.; Sousa, J. Gamification in Remote Teaching of SE Courses: Experience Report. In Proceedings of the 34th Brazilian Symposium on Software Engineering, Natal, Brazil, 19-23 October 2020; pp. 844-853.

17. Nicholson, S. Creating Engaging Escape Rooms for the Classroom. Child. Educ. 2018, 94, 44-49. [CrossRef]

18. Ross, R. Design of an Open-Source Decoder for Educational Escape Rooms. IEEE Access 2019, 7, 145777-145783. [CrossRef]

19. Sanchez-Martin, J.; Corrales-Serrano, M.; Luque-Sendra, A.; Zamora-Polo, F. Exit for success. Gamifying science and technology for university students using escape-room. A preliminary approach. Heliyon 2020, 6, e04340. [CrossRef]

20. Braun, V.; Clarke, V.; Boulton, E.; Davey, L.; McEvoy, C. The online survey as a qualitative research tool. Int. J. Soc. Res. Methodol. 2020, 1-14. [CrossRef]

21. Borrego, C.; Fernández, C.; Blanes, I.; Robles, S. Room escape at class: Escape games activities to facilitate the motivation and learning in computer science. JOTSE 2017, 7, 162-171. [CrossRef]

22. Vergne, M.J.; Simmons, J.D.; Bowen, R.S. Escape the Lab: An Interactive Escape-Room Game as a Laboratory Experiment. J. Chem. Educ. 2019, 96, 985-991. [CrossRef]

23. Waring, M. Grounded Theory. In Research Methods and Methodologies in Education; SAGE: Thousand Oaks, CA, USA, 2021; pp. 119-134.

24. Ho, A.M. Unlocking Ideas: Using Escape Room Puzzles in a Cryptography Classroom. PRIMUS 2018, 28, 835-847. [CrossRef]

25. Lien, Y.; Wang, C.; Wang, S.; Li, C.; Hou, H. Designing an Escape Room Educational Game and a Game-based Learning Activity for Science Learning: Analysis of Learning Achievement and Flow State. In Proceedings of the 2019 8th International Congress on Advanced Applied Informatics (IIAI-AAI), Toyama, Japan, 7-11 July 2019; pp. 1049-1050.

26. Almqvist, L.; Uys, C.J.E.; Sandberg, A. The concepts of participation, engagement and flow: A matter of creating optimal play experiences. South Afr. J. Occup. Ther. 2007, 11,1-6.

27. Reschly, A.L.; Huebner, E.S.; Appleton, J.J.; Antaramian, S. Engagement as flourishing: The contribution of positive emotions and coping to adolescents' engagement at school and with learning. Psychol. Sch. 2008, 45, 419-431. [CrossRef]

28. Alsawaier Raed, S. The effect of gamification on motivation and engagement. Int. J. Inf. Learn. Technol. 2018, 35, 56-79. [CrossRef]

29. Kuric Kardelis, S.; Calderón Gómez, D.; Sannmartín Ortí, A. Educación y brecha digital en tiempos del COVID-19. Perfiles y problemáticas experimentadas por el alumnado juvenil para continuar sus estudios durante el confinamiento. Rev. Sociol. Educ. RASE 2021, 14, 63-84. [CrossRef]

30. Gaintza-Jauregi, Z. La simulación como estrategia metodológica en la Facultad de Educación de la Universidad del País Vasco. Rev. Electrón. Educ. 2020, 24, 233-250. [CrossRef]

31. Anguas-Gracia, A.; Subirón-Valera, A.B.; Antón-Solanas, I.; Rodríguez-Roca, B.; Satústegui-Dordá, P.J.; Urcola-Pardo, F. An evaluation of undergraduate student nurses' gameful experience while playing an escape room game as part of a community health nursing course. Nurse Educ. Today 2021, 103, 104948. [CrossRef] [PubMed]

32. Edwards, T.; Boothby, J.; Succheralli, L. Pediatric escape room: An innovative teaching-learning strategy. Teach. Learn. Nurs. 2021. [CrossRef]

33. Nybo, S.E.; Klepser, S.A.; Klepser, M. Design of a disaster preparedness escape room for first and second-year pharmacy students. Curr. Pharm. Teach. Learn. 2020, 12, 716-723. [CrossRef] 
34. Vidergor, H.E. Effects of digital escape room on gameful experience, collaboration, and motivation of elementary school students. Comput. Educ. 2021, 166, 104156. [CrossRef]

35. López-Mondéjar, L.M.; Pastor, L.M.T. Development of Socio-emotional Skills through Cooperative Learning in a University Environment. Procedia Soc. Behav. Sci. 2017, 237, 432-437. [CrossRef]

36. Pérez, E.; Gilabert, A.; Lledó, A. Gamificación en la educación universitaria: El uso del escape room como estrategia de aprendizaje. In Investigación e Innovación en la Enseñanza Superior. Nuevos Contextos, Nuevas Ideas; Octaedro, E., Ed.; Octaedro: Alicante, Spain, 2019.

37. Sierra Daza, M.C.; Fernández-Sánchez, M.R. Gamiicando el aula universitaria. Análisis de una experiencia de Escape Room en educación superior. Rev. Estud. Exp. Educ. 2019, 18, 105-115. [CrossRef] 